\title{
MODES OF ORAL TESTIMONY IN ETHNOGRAPHIC FILM \\ FORMAS DE TESTEMUNHO ORAL EM FILMES ETNOGRÁFICOS
}

\section{Paul Henley}

paul.henley@manchester.ac.uk

Professor of Visual Anthropology at The University of Manchester, Granada Centre for Visual Anthropology (Centro Granada de Antropologia Visual, Universidade de Manchester).

\section{RESUMO}

Este artigo parte do pressuposto de que o uso do termo "entrevista" para descrever performances verbais oferecidas em resposta aos questionamentos ou solicitações dos cineastas é restritivo e até mesmo enganoso quando empregado no contexto da realização de filmes etnográficos. Por isso, sugere-se o termo "testemunho oral". Ademais, considera-se uma ampla variedade de formas nas quais o testemunho oral tem sido usado no filme etnográfico e em gêneros relacionados.

Palavras-chave: Filmes etnográficos. Testemunho oral. Arquivos visuais. Memória incorporada.

\begin{abstract}
This article proposes that the use of the term 'interview' to describe verbal performances offered in response to a series of questions from a film-maker is restrictive and even misleading, particularly when employed in the context of ethnographic film-making, and suggests that the term 'oral testimony' be used instead. It then considers a broad range of modes in which oral testimony has been employed in ethnographic film and related genres.
\end{abstract}

Keywords: Ethnographic filmmaking. Oral testimony. Visual archives. Embodied memory.

\section{THE INTERVIEW AS ORAL TESTIMONY}

The interview, broadly defined, is found in many different forms in documentary film: at one extreme, there is the casual conversational exchange between film-maker and subject; at the other, there are formal, almost interrogational interviews, in which the interviewer proceeds through a preconceived schedule of questions. In between, one finds many different forms in which the relative weighting of the parts played by interviewer and subject can vary considerably. So too can the degree to which the questions remain in the final edited version of the film. Another variable is the number of subjects: whilst most commonly there is only a single subject, sometimes there may be two or more, with one of the subjects acting as a proxy interviewer for the film-maker. Or there may be a whole group of people who set about discussing a topic given 
to them by the film-maker, in the manner of a focus group. So varied are these forms that one might even question whether the term 'interview' should be employed to cover all of them. But what they all have in common is that they involve a verbal performance of some kind that has been motivated by a question or request originating with the film-maker.

Whatever its form, the 'interview' encountered in documentary film is typically very different, both in nature and function, to the 'interview' conducted for the purposes of general ethnographic research. The aim of the latter is primarily to gather information: by contrast, the aim of the documentary film interview is to provoke a verbal performance that will impart information to an audience, but one in which the manner of the performance itself may be just as important as the information. Therefore, in framing their questions, the documentary film interviewer should aim to encourage the subject to produce a narrative rather than a bare statement of facts. Thus, rather than asking 'When were you born?', which will probably produce no more than a single date, the interviewer should aim to get the subject to tell a story, with a prompt such as 'Tell me about your early life'. In response to this latter kind of prompt, the subject is likely to provide not only their date of birth, but also a great deal more, which will make for a much more interesting film.

There is also a major difference in the sheer quantity of 'interviews' that are typically conducted in each case. One standard research methods text-book states that even a small ethnographic research project requires 40-60 interviews 'to generate sufficient data to be worthwhile' (BERNARD, 2005, p. 221). The number of 'interviews' conducted for a documentary film is typically very much smaller. Even in Shoah, Claude Lanzmann's epic 91/2 hour documentary on the Holocaust, there were only 33 principal interviewees. As in Shoah, a range of contrasting views may be offered by the interviewees in a documentary film: but there is no way in which these views, however diverse, could be considered representative of a wider sample of respondents in any precise statistical sense. In practice, documentary film 'interviews' are generally more about the purveying of opinion about fact than they are about the communication of fact itself.

For these various reasons, particularly when referring to ethnographic documentary, I much prefer the phrase 'oral testimony' to the term 'interview'. The latter is too infused, it seems to me, with inappropriate connotations - on the one hand, of the sit-down journalistic interrogation and, on the other, of the systematic data-gathering practice of the ethnographic field researcher. The phrase 'oral testimony' is preferable, I would argue, because it acts as a reminder that the verbal performances offered by the subjects of an ethnographic film are more akin to witness statements in a court of law. Although they may be factually correct, they are also, at the same time, merely a statement about the world offered from the particular perspective of the witness in question.

\section{ORAL TESTIMONY IN ETHNOGRAPHIC FILM}

Within the genre of ethnographic film as a whole, the importance of oral testimony has varied considerably. Given that the interview is an essential component of ethnographic fieldwork, it is perhaps not surprising that when academic anthropologists have taken up cameras, they have tended to put oral testimony at the heart of their production practice. A similar dependence on oral testimony is evident in the ethnographic documentaries made for television, which for many years was the principal patron of ethnographic filmmaking in Britain. This too can be considered a transposition of a pre-existing mode of enquiry: it has been argued that the formal interview was first appropriated by 
print journalists from legal procedures developed for the interrogation of witnesses in court; since factual television is essentially a journalistic endeavour, this interrogatory format was subsequently adopted as a central strategy of television film-making (WINSTON, 1995, p. 138-142). When television turned its attention to ethnographic subjects, it is not surprising then that the formal interview was adapted to this subject-matter too.

In contrast, for ethnographic film-makers coming from a more cinematic background, oral testimonies have been much less important. They are almost completely absent, for example, in the work of Robert Gardner, arguably the most cinematic of the North American ethnographic documentarists. The only examples that come to mind are to be found in Rivers of Sand (1974) and Ika Hands (1988). In the first case, there is a prolonged testimony at the beginning of the film by one of the leading female subjects, lamenting the hard lot of women amongst the Hamar pastoralists of Ethiopia. In the latter case, there is a surprisingly conventional formal interview, again at the beginning of the film, with the Colombian anthropologist Gerardo Reichel Dolmatoff, which is also used to provide voice-over comment at various points thereafter. But, in general, as a film-maker, Gardner has shown very little interest in including his subjects' voices in his films, be it as oral testimony or in any other form, and even when he has done so, as in his masterwork about funeral practices in Varanasi, Forest of Bliss (1986), he has declined to subtitle them so that the content of what they are saying is incomprehensible to most audiences.

Jean Rouch also mostly eschewed oral testimony in his ethnographic films, though he certainly did use it on occasion, most notably in Chronicle of a Summer (1960). Here one encounters oral testimony in a number of different guises. At the beginning of the film, there are the famous 'vox-pop' interviews when Marceline and Nadine go round asking people, 'Êtes-vous heureux?' - 'Are you happy?'. Then there are the focus-group-like discussions, often around a dining table with plenty of evidence of the French love of good food and wine, and also of clouds of smoke from untipped cigarettes. There is also an example of a proxy interview, when the factory worker, Angelo, interviews Landry, an African student, about his experience of racism in France. The informality of these interviews contrasts with the intense, almost psychoanalytical interviews conducted by Edgar Morin, the co-director, with himself in shot, first with Marceline and her boyfriend Jean-Pierre, and then later with Marilou, another major character, about their inability to form authentic personal relationships under the then-present social conditions. Different again is Marceline's soliloquy about her experiences in a Nazi concentration camp as she walks across the Place de la Concorde. Despite its apparent spontaneity, this too was a verbal performance, motivated by the film-maker, in which Marceline was responding to a request from Rouch to walk across the square and say whatever came into her head (though what she chose to talk about was undoubtedly influenced by the fact that they had deliberately gone to a square where, earlier that same day, a feature film about the German Occupation of France had been in production). Yet another form of oral testimony is to be found in the scene close to the end of the film when the subjects are gathered together in a cinema and asked to say what they think about a preliminary assembly of the rushes ${ }^{1}$.

But Chronicle is exceptional within Rouch's documentary work as a whole. There is plenty of oral testimony in his early 'ethnofictions', Jaguar and Moi, un Noir, where it takes the form of voice-overs that the subjects recorded in response to the rushes. Much later in his career, between the late 1970s and early 1990s, he produced a series of 'ciné-portraits' of various friends and colleagues in which oral testimony in the form of conversations between himself and the subjects predominates. But in the films set in West Africa that make up the main body of his ethnographic documentary work, Rouch very rarely uses any form of oral testimony, and certainly no formal interviews. Indeed, interviews were 
so alien to Rouch's general praxis that in the well-known essay, 'The Camera and Man', which is the nearest that he came to a summary description of his methods, he does not even mention them (ROUCH, 1995).

Similarly, in Observational Cinema, at least in its purest form, formal interviews are regarded with great suspicion. In the three years that I spent learning to make observational documentaries at the National Film and Television School in the 1980s, we were never once given any instruction in how to shoot formal interviews. Observational Cinema, we were encouraged to believe, should be about showing, not telling. We should be interested in showing how our subjects actually lived their lives rather than in giving them the opportunity to tell us how they did so. 'Talking heads' was almost a term of abuse, one that was considered synonymous with the prosaic, information-based documentaries of the kind that were common on television, but which would certainly never be found in the cinema.

But, in actual practice, many leading observational film-makers have used oral testimony, as defined more broadly above, and very effectively too. In fact, I find it hard to think of a single observational film that does not involve some kind of oral testimony as an important feature. But in an observational film, these verbal performances are usually presented not as interviews as such, but rather as 'conversations' between the film-makers and the subjects, apparently arising out of the normal flow of events. In the final edited version, they are presented as spontaneous one-off events rather than returned to time and again in an achronological manner, as in a conventional 'talking heads' television documentary.

Yet for all their informality and apparent naturalism, the 'conversations' found in observational cinema are interviews in all but name. If they are conversations, they are rather unusual ones in that they do not involve the turn-taking that is one of the most important defining features of a conversation as a linguistic phenomenon. Although they may make allusion to the film-makers and in this sense be admirably reflexive, there is no parity of exposition in an observational 'conversation': much more is revealed by the subjects about their lives than the film-makers do about theirs. But none of this should be a source of shame or scandal. On the contrary, by the very richness of the oral testimony that they have managed to generate in this discrete way, observational film-makers have shown just how effective oral testimonies tailored to the subjects' communicative repertoires can be.

I am thinking particularly here of David and Judith MacDougall's films about the pastoralist peoples of Kenya and Uganda, though the same general comments could apply to any number of other observational films. In the MacDougalls' African films, 'conversations' often take place entirely informally, under a shade tree and, no doubt, they did indeed sometimes arise spontaneously. However, although they may not have been immediately initiated by a leading question from the film-makers (though sometimes an intertitle indicates that they were), there can be little doubt that the conversations in these films largely took place on account of the presence of the film-makers. Sometimes these conversations arose when a group of subjects was asked by the film-makers to discuss a particular topic: there is an example of this in Kenya Boran (1974), a film that David MacDougall made about the Boran pastoralists of the title, though in this case, the co-director was James Blue rather Judith MacDougall. As David later described it:

Once, during a typical men's conversation over tea, we asked a man named Guyo Ali to raise the subject of the government's advocacy of birth control. The result was an explosion of disagreement from Iya Duba, the most conservative old man present. In his reply, he set forth 
his view of the logic of having many children in a pastoral society, followed by an impassioned defense of cattle and cattle herding, which he was unlikely to have delivered without some such strong provocation. It was, in fact, the clearest expression of Boran economic values that we encountered during our stay (MACDOUGALL, 1995, p. 127).

The ability to accommodate the precise format to the cultural context in which the film-making is taking place is surely the key to the successful use of oral testimony in ethnographic documentary. In some non-Western cultural contexts, the elicitation of oral testimony has not been problematic. The pastoralist peoples of East Africa seem particularly adept at providing it. Not only is there the example of the Jie and the Turkana who feature in the films of the MacDougalls, but this is also true of the highly eloquent interlocutors, both male and female, that one discovers in the films that Melissa Llewelyn-Davies made amongst Maasai in Kenya. A similar degree of eloquence is to be found in the many films that Leslie Woodhead and David Turton made about the Mursi of Ethiopia as well as in those that Jean Lydall and Ivo Strecker have made about the Mursi's neighbours, the Hamar.

The facility with which pastoralist peoples of East Africa have been willing and able to supply oral testimony to visiting film-makers is surely connected to the importance of public speaking in their societies². But in other cultural contexts, oral testimony has proved very difficult to elicit. When the MacDougalls moved to Australia and began working with Aboriginal communities, they found that they had to accommodate their film-making strategies to a very different set of conventions about speaking in public. In this cultural environment, knowledge is often restricted and only people of certain particular statuses are permitted to hold it (MACDOUGALL, 1992). Similarly, in my own experience of filming in a variety of different cultural contexts in Venezuela, I have found that whilst the people of Cuyagua, a village on the Caribbean coast, who are of African descent, were generally only too pleased to produce a range of different kinds of verbal performance, the members of the various Amerindian groups with whom I have worked were often reluctant to provide any kind of oral testimony in front of a camera.

What it is essential to recognise is that the formal interview of the kind that is the stock-in-trade of many forms of television documentary is a very specific kind of cultural performance that, in other contexts, may not sit well with the subjects' repertoires of linguistic communication, nor with their notions of what the appropriate relationship between interlocutors should be. A very particular problem pertains to the interrogational format developed for the current affairs documentary. Although it may well have proved an effective means of interviewing Western politicians, scientific experts or film stars - or indeed members of the general public who are familiar with the format and know how to play the game - it is potentially problematic in that it is based on the unspoken convention that the interviewer is an advocate, who bears no personal grudge against the interviewee, but who has the democratic obligation, as a representative of some broader audience, to ask awkward questions. Even Western politicians who might acknowledge their accountability to that broader audience sometimes have difficulty in taking these questions at face value rather than as a form of impertinence. But in the cultural contexts in which ethnographic film-makers often work, to ask such questions would be regarded as nothing less than an act of outrageous rudeness.

However, in my view, none of this amounts to an argument against the use of oral testimony in ethnographic film-making as a matter of principle. Provided oral testimony is elicited with an appropriate degree of sensitivity to the culturally specific communicative norms of the subjects, then I see no reason why it cannot be a valuable method for ethnographic documentary-makers. 


\section{ORAL TESTIMONY AS A PRACTICAL STRATEGY}

In addition to being generally in line with journalistic tradition, one of the reasons why formal interviews are so common in television documentary is that they represent a quick, and therefore cheap, way of making a film: rather than following a subject over a prolonged period of time, as an observational film-maker might do, waiting for that epiphanous moment that will reveal some highly significant aspect of character or worldview, it is obviously much more expedient to set up a formal interview, and then ask a few direct questions. Indeed, in a budgetary environment in which you may have only five days to shoot a 30-minute documentary - as has been my experience working as a freelance documentary-maker for British television - the formal interview may be the only way to represent key aspects of the subjects' lives.

The formal interview can also be a very useful device at the editorial stage. In the television environment, where running time is predetermined down to the last second, it is often necessary to resort to an interview to make complex points as succinctly as possible, even if some of the cultural nuances or ambiguities are thereby lost. A formal interview allows great flexibility: one can use it sparingly or extensively in synch as needs be or, provided it has been shot in an environment with low background noise, one can fillet out snatches of it and use it as voice-over. The greatest practical downside of the interview is that it usually consumes a great deal of stock, but now that digital video is the medium most used by documentarists, this is much less of a problem than it used to be in the heyday of $16 \mathrm{~mm}$ when stock was very much more expensive.

Oral testimony can also be very useful for the ethnographic documentarist, even when time pressure is not an issue. Most obviously, it can be a very efficient mechanism for filling out cultural or political contexts that are not directly observable. Melissa Llewelyn-Davies uses formal interviews very effectively for this purpose in The Women's Olamal (1984), a film that concerns the organisation of a Maasai women's fertility ceremony. Although the main action of the film shows the dramatic events leading up to the holding of the olamal ceremony itself, it is punctuated throughout by a series of interviews in which a number of Llewelyn-Davies's long-standing informants discuss the connection between a woman's fertility and cattle ownership. They explain that a woman cannot own cattle, which are the principal basis of wealth in Maasai society, but only look after those of her husband. Should he predecease her, which is very likely given the usual disparity of age on marriage, then his cattle, including those that she herself has been tending, are passed on to his sons or, in their absence, to other male relatives. If she has children, then a widow can generally rely on them to look after her. But if a widow is childless, she becomes in effect destitute, dependent on charity, which cannot be guaranteed. Hence the great importance to women of the fertility ceremony which is the subject of the film. Although it is possible to conceive of a series of situations that might have thrown up this sort of contextualizing information and which one might have filmed observationally, there is no assurance that these would have arisen during the period of filming, and they certainly would not have explained the rationale of the event so economically.

Oral testimony can also be valuable in and of itself as a particular kind of performance that is inflected by local cultural norms of speaking, gesture and story-telling. This was my experience in shooting The Legacy of Antonio Lorenzano (2000), a film about the cultural legacy of the recently deceased headman of a Warao village in the Orinoco Delta in Venezuela. In the course of the film, a number of Lorenzano's descendants and other associates recall his performances as musician, artisan, and healer, and repeat his counsels about how various traditional customs should be observed. Some individuals were unable 
to respond to my attempts to elicit oral testimony except in the most stultified way. But others, who had clearly mastered the conventions of speaking publicly in Warao society, responded by giving an almost theatrical performance. Perhaps the most striking example in the film is the account of Warao funerary customs given by Lorenzano's grandson, Segundo Rivero. His eloquent account is supported by a spontaneous choreography of graceful arm gestures combined with bodily movements around the small space of his house.

Oral testimonies can also be revealing in a more subtle way too, offering an insight into the interplay between culture and experience. This may be communicated not only by how the subject chooses to say what they want to say but also through any number of paralinguistic or non-verbal aspects of the performance, such as the speed of delivery, the gesture of a hand, the trace of a smile playing around the lips, a momentary hesitation. Through Segundo's eloquent soliloquy in The Legacy, for example, as he struggles to maintain his composure and hold back his tears, we become aware of the powerful emotional connection between funerary customs, which involve an elaborate process of secondary burial, and the Warao sense of who they are today. All this would have been completely lost in a textual transcription of what he actually said.

\section{ORAL TESTIMONY AND VISUAL ARCHIVES}

Another obvious role for oral testimony in ethnographic documentary is as a means to refer to social or cultural phenomena that cannot be directly observed for the simple reason that they are no longer practised. Films based on the relating of subjects' memories are an important constituent of the canon of ethnographic film, but the modes through which memory-based oral testimonies have been elicited and presented have been very varied.

One of the most common modes consists of a series of formal oral testimonies that are intercut with visual archives of one sort or another, usually films or photographs. This archive material is often employed in one of two principal ways. Most straightforwardly, it may be used to provide illustrative visual evidence - usually in support of what is being said, though it can sometimes be used in contradiction. Visual archive can also be used in a more oblique manner, to evoke a general sense of the time and place within which the events being spoken about took place. Both uses of visual archive can be very effective in lending authority and interest to what is being said in the interview. They can also both be very useful in a pragmatic editorial sense: not only can it be good to have a relief from a 'talking head', which can become tedious however interesting the content of what is being said, but the cut to archive material also provides an opportunity to eliminate redundant material without the need for a visual 'jump cut'. However, problems can arise when the audience either reads too much into the evidence offered in the archival material or misinterprets an evocative use of archival material as an evidential use.

The simplest use of archival material as supporting evidence entails no more than providing a visual counterpart to what a 'talking head' is saying. Thus, say, a male subject's verbal reminiscences of his childhood seaside holidays could be illustrated in an entirely unproblematic way by a photograph of himself and his mother on the beach, with bucket and spade in hand, and smiles on their faces. If we set aside the possibility that the hypothetical film-maker, in this case, is not actively seeking to mislead the audience through photomontage or the like, the photograph establishes such simple matters as the fact that the subject and his mother were there, what the beach was like, what their bathing costumes were like, and that they were smiling at the moment at which the photograph was taken. But, clearly, even in this simple example, there is the possibility 
of misunderstanding since an audience could conclude that because the subject is smiling in the photograph, he must have enjoyed a happy childhood, which might not have been true.

Archival material is often used in an evocative manner for the entirely pragmatic reason that no more direct representation of the events recalled by the person giving the oral testimony actually exists. There are various examples of this usage in We were Born to Survive (1995), a film directed by Paul Okojie and which I myself produced. This film was constructed around a formal master interview with the Black activist from Manchester, Kath Locke, conducted shortly before she died in 1992. Early on in the interview, Kath refers to her first experience of racism when she was a child growing up in Blackpool, which occurred when she was walking on the seafront and met a woman who asked her where she was from. When Kath replied that she was from Blackpool itself, the woman became angry and said, 'You can't be from here - you're Black!'. We had no footage of this event, of course, so we supported it instead with some amateur footage of the Blackpool seafront shot at roughly the same time in the 1920s. This footage had absolutely no connection with Kath but at least it showed that the population of Blackpool at the time was overwhelmingly White.

Somewhat later in the film, we again used archival footage to support another reference to Kath's experiences of racism when, as a young woman, she and her family were ushered into a back room at the marriage of some White relatives. Here too, as there was no visual record of this particular event, we used some amateur footage, this time taken at the wedding of the parents of the researcher on the film, Caroline Dover. This was very brief, and the subjects were mostly in silhouette so it was not easy to identify them. But we felt that it captured something of the feeling of what weddings were like in Britain in the 1950 s, which was the period to which Kath was referring

We had no qualms about using this archival footage of the wedding because we believed that it was clear from the context that the material was being used in a generic, evocative manner rather than as direct evidence of theparticular experience of racism to which Kath Locke was referring. However, there is always a risk that in any situation like this, some viewers may misinterpret an evocative use of visual archive as an evidential usage. It is just possible that someone in the eventual audience might have recognized Caroline's parents in the footage and from this have concluded that it was at their particular wedding that Kath Locke had suffered this insulting treatment. But given that it was very difficult to construe the identity of the figures in silhouette, we thought that in this particular case, this was highly unlikely.

Films in which oral testimony is supported by visual archive have been criticized by David MacDougall on account of this potential unreliability. MacDougall suggests that visual archive can not only mislead an audience about matters of fact but also lend a spurious neutrality to the accompanying oral testimony, masking its partiality in both senses of the term. By treating reminiscence as unproblematic, MacDougall argues that films of memory based on visual archives can 'somehow dispose of having to define, or speak from, their own particular interests'. This leads, he proposes, to 'a certain emptiness at the heart of such authorship, a fundamental lack of conviction' (MACDOUGALL, 1998, p. 240).

In the last analysis, as a viewer, one depends on the integrity of the subjects to relate the past as honestly as they can, and on the film-maker not to intentionally mislead by using visual evidence in a dishonest way. But clearly, one cannot guarantee that this will always be the case. We must also recognize that even if both the subject's and the film-maker's intentions are impeccable, there is still considerable potential for a misreading by the audience. And yet, despite these potential shortcomings, I continue to believe that archive-based 
films can still play a valuable role as a particular variant of ethnographic documentary. After all, the integrity of subjects and film-maker may be compromised in any form of documentary, not just in films that are based on visual archives. Equally, any form of documentary is vulnerable to 'aberrant readings' by its audiences. There seems to me therefore to be no strong grounds for singling out archive-based film-making for rejection on this basis alone.

Moreover, although MacDougall is certainly right about the failure of some archive-based films to interrogate sufficiently the interests of the subjects, this need not necessarily be the case. Nor need it be the case that every filmmaker who uses visual archive lacks conviction in what they are doing. Here, if I were to cite only one counter-example, I would look no further than $A$ Cry from the Grave (1999), directed for British television by one of the founding figures of the Granada Centre, Leslie Woodhead.

This film offers a devastating retrospective account of one of the worst atrocities of the civil war in former Yugoslavia, the Srebrenica massacre. To do so, it uses archive material in the form of camcorder footage produced by the various different sides involved in the conflict: the Serbian forces of General Ratko Mladic who perpetrated the massacre; the aides of Naser Oric, the Muslim leader also accused of atrocities and the Dutch UN peacekeepers who failed to keep the peace. It even uses footage shot by the victims, that is, by anonymous cameramen whose footage was recuperated after they had been killed. This archival material is sometimes used illustratively, sometimes evocatively, sometimes in the sense that it was intended, at other times against itself. But the sources of these various types of footage are always identified and their underlying motivations interrogated in the course of being skilfully woven together with oral testimonies and other footage shot by Woodhead's own crew two or three years after the event. Nor can there be any doubt about the conviction underlying the film since it is abundantly clear where the sympathies of the film-maker lie. This film may not be motivated by explicitly ethnographic intentions, but it nevertheless serves as a model that ethnographic film-makers would do well to emulate should they wish to use visual archives in conjunction with oral testimony.

\section{ORAL TESTIMONY AND EMBODIED MEMORY}

Although the use of visual archives may well prove very effective in certain situations, there may be others in which use of literal visual images is in direct conflict with the purposes of a film based on oral testimony. This was the conclusion that I arrived at when cutting The Legacy of Antonio Lorenzano. In doing research for this film, I came across quite a substantial archive, dating from the 1950s and 1960s, of magnificent black and white photographs of the Warao as well as a film made in collaboration with a missionary order working in the Delta. The aesthetic quality of some of this material was remarkably good and it evoked very strongly a bygone era when missionary nuns still wore wimples and the mission schools, now rusty and decaying, still thronged with children. My first thought was to use this material to complement the oral testimonies in the film that referred to Lorenzano's childhood, when he attended one of these mission schools as a boarder. But as I began to cut the archive material in, I realized that it was turning the film into a sort of informational historical biography whereas my goal was to make a film about what the memory of Lorenzano meant to those who had survived him. I therefore took it all out again, apart from two brief images of Lorenzano himself, in later life and in colour, which were intended to give the viewer a sort of visual hook on which to hang all the testimonies about him offered by the subjects. Instead of cutting away to archival materials, I tried to stay with the subjects' oral testimonies in synch as 
much as possible, and when I did need to use supporting material, I relied on contemporary images that I had shot myself.

A particularly celebrated example of a film whose director rejected the use of visual archive is Shoah, Claude Lanzmann's epic documentary about the Holocaust, released in 1985, which I referred to at the beginning of this chapter. In part, the absence of visual archives in Shoah is because Lanzmann found very few moving image sequences that related to the actual process of extermination (as opposed to the well-known material shot by Allied cameramen arriving at the camps at the end of the war). The archives that did exist were either suspect because they were shot by the Germans for propaganda purposes, or were too slight to have any impact (CHEVRIE; LE ROUX, 2007, p. 40-41). But Lanzmann also rejected the use of visual archives because of the associated implication that the Holocaust was an event that could be consigned to the past, which was precisely the idea that he most strongly wanted to contest. Speaking of archival footage 'almost with disgust', Lanzmann told one of his interviewers, 'You must understand, I did not make an historical film' (HOBERMAN, 1996, p. 325)3. Instead, Lanzmann's aim was to present the Holocaust as an ongoing and indelible collective trauma that should simply be confronted in all its full enormity with no attempt at explanation or understanding (LANZMANN, 2007). Nor should its victims ever be forgotten. To underline this last point, each of the four parts of the film, as well as the book-length transcript of the soundtrack that he later published, begins with an epigraph taken from Old Testament Book of Isaiah: 'I will give them an everlasting Name' (Idem, 1985).

Therefore, instead of turning to visual archives to support the oral testimonies that form the main backbone of the film, Lanzmann uses various forms of embodied memory, both animate and inanimate ${ }^{4}$. There are many shots of rural scenes, silent except for the wind and some birdsong, in which the vague outline of rows of blockhouses, or a rusty railway track disappearing amongst the trees, although now barely discernible, still bear witness to the outrages that were once committed in those places, often, we are reminded, on the most beautiful of summer days. There are also many shots of railway rolling stock, including the very boxcars in which the victims were transported to the camps, not to speak of the rusting remains of the camps themselves, which are approached time and time again, in the manner of a musical leitmotiv. In this sense, Lanzmann explains, Shoah is a 'topographical' film that builds 'from the ground up' (CHEVRIE; LE ROUX, 2007, p. 39). But the oral testimonies are also supported by more animate embodied memories, perhaps the most shocking example being the throat-cutting gesture that Polish peasants recall that they made to the Jewish people trapped in those passing boxcars.

These embodied memories were not hit upon by chance. Lanzmann dedicated great quantities of stock to the 'topographical' shots of the countryside and the camps, even though at the time that he was shooting them, he did not know precisely how he would use them. Not only did he bring the railway rolling stock out of retirement specifically for the purposes of the film, but also one of the engine drivers, Henrik Gawkowski. The image of Gawkowski looking out of the locomotive cabin as the train approaches Treblinka has become an icon of the film, but this was an image that was entirely set up by Lanzmann. The throat-cutting gesture that recurs a number of times was similarly set up. Having heard about it through Richard Glazar, one of the Jewish survivors to whom the gesture had been made, Lanzmann asked his Polish subjects to re-enact it, which they did very readily. Although they claimed that they used to make this gesture to 'warn' the Jews of their impending fate, the sadistic relish with which they make the gesture some thirty years later suggests that the motivations underlying it were far from altruistic 5 (Ibidem, p. 43).

In a rather different register, Lanzmann traces another embodied memory of the shoah in the continued existence of certain industrial entities that lent 
their efficient technical know-how to the 'processing' of thousands of victims every day. At one point, towards the end of the second part of the film, there is a series of tracking shots, evidently taken from a car, of the industrial landscape of the Ruhr. These provide the background for a reading out, by Lanzmann himself, in menacingly precise tones, of a technical report prepared for the Saurer vehicle manufacturer ${ }^{6}$. This was written in 1941 by the SS official who was in charge of exterminations around Chelmno, a small town in Poland. In numbingly euphemistic technical language, the official suggests various modifications to the design of the Saurer vehicles that would greatly improve their efficiency as 'gas vans'. These were the vehicles in which groups of people were sealed in airtight compartments and then poisoned with the vehicle's own exhaust fumes. As this report is being read out, the shots of power stations and motorways suddenly give way to a shot of a modern truck taken out of the rear window of the film-makers' car. The camera zooms in on its radiator to reveal the Saurer badge. Although this particular truck was probably on some entirely innocent mission, this shot takes on a deeply ominous significance, giving the impression that even in the 1970s, the perpetrators of the Holocaust are somehow still at large.

Nor does Lanzmann use embodied memories merely to support oral testimonies: he also uses them to provoke oral testimonies, particularly from Jewish survivors, some of whom were reluctant to speak about their experiences. One notable example involves the survivor Abraham Bomba, who is interviewed whilst giving a haircut in a barber's salon. Bomba had spent much of his life after the war working as a barber in New York, but by the time that Lanzmann came to make his film, he had retired and was living in Tel Aviv. When he was in the Treblinka camp, he had had the gruesome job of cutting off the hair of prisoners who were about to be gassed. Amongst those whose hair he had to cut were people from his own village in Poland: although he knew that they were about to be murdered, he had to pretend that the haircutting was for purely hygienic reasons.

But in Tel Aviv, in his tropical shirt with the sparkling blue sea beyond, Bomba would talk only in the most dispassionate way about his experiences. By asking him to return to a barber's salon and by interviewing him whilst actually cutting someone's hair, Lanzmann obliged Bomba to relive his time in Treblinka in an embodied manner. The result is a testimony of 'lacerating vividness', as one commentator has described it (HOBERMAN, 1996, p. 324). At one point, Bomba is on the verge of breaking down, but far from releasing him from the task, Lanzmann urges him to continue. 'Go on', he says, 'it's important', and Bomba continues, seemingly in agreement that his testimony is necessary to uphold the everlasting Name of the victims of the Holocaust.

\section{ORAL TESTIMONY AND DISEMBODIED MEMORY}

Although memories can be very vivid and intense, particularly when associated with traumatic experiences as in this last case, more generally human memory is proverbially aleatory and unreliable, with moments of clarity occurring in the midst of absence and inconsistency. Although one might demur from David MacDougall's generalised criticism of films of memory based on visual archives, he is certainly correct in suggesting that archival films and photographs, or indeed any other physical objects or landscapes that are used in a 'topographical' manner to represent and endorse memories described by the subjects of a film are merely, as he puts it, 'external signs of remembering' that can be far removed from the actual experience of memory (MACDOUGALL, 1998, p. 232).

A film that attempts to capture these more abstract qualities of the experience of memory is In the Light of Memory (2010), a film shot and directed by Alyssa 
Grossman. This film concerns the memories retained by the people of Bucharest, the capital of Romania, about life in their city prior to the fall of the Communist regime of Nicolae Ceausescu in 1989. But apart from one or two brief and distant shots of buildings at the beginning of the film, the audience never actually gets to see the urban parts of the city. Instead, the film is set in Cismigiu Gardens, a quiet and elegant public park that is frequented by people from all walks of life and of all ages, and which is a place considered by Bucharest residents themselves to be a site of nostalgia, a place where they go on Sunday afternoons in order to escape from the normal time regimes of the city. As such, it is a location that is particularly apt as a backdrop to the evocation of the memory of times past.

Nor does the audience actually get to see the subjects providing the oral testimony in this film. This testimony takes the form of a series of disembodied and anonymous voice-over statements extracted from much longer interviews that were originally shot in synch. Delivered in a quiet, almost confidential manner, these statements make only oblique reference to political matters (in relation to food rationing, for example, or to Ceausescu's housing demolitions). Instead, they consist of a series of highly personal reflections comparing the experience of living in Bucharest then and now, and of speculations on how interpersonal relationships and the sense of time have changed, as well as on the nature of memory itself.

The fragmentary nature of memory is further suggested by a series of tracking shots that are a recurrent feature of the film. These were shot from a camera attached at right angles to the saddle of a bicycle that Grossman wheeled along the principal paths of the park. These paths are bordered by a continuous line of green wooden benches and as the camera passes by, it affords a brief glimpse into the lives of the people sitting on those benches. Sometimes people engage with the camera, though many are apparently not aware of it or choose to ignore it. Here, some elderly ladies gossip about some mutual acquaintances who are too trusting; there, a man on a mobile phone reassures his wife that he is on the way home; three boys, giggling, stand on the benches and position their feet in front of the camera to show off their new trainers; several couples embrace, indifferent to the passing cinematographer.

These tracking shots are intercut with various sequences featuring a photographer who has operated in the park as long as anyone can remember. He sets up the tools of his trade: a board of fading portraits and a stuffed deer that has seen better days. A mother brings her child to be photographed sitting on the deer and soon other clients follow. But when the photographer tells one lady that her prints will not be ready 'until Monday', she offends him by asking for a receipt for the down-payment. 'If I may say so,' comments a bystander, 'you don't come here often. This man has been here since I was a kid and I'm 57 now'. Later, an elderly woman approaches the film-maker's camera. She explains that she has come to have her photograph taken so that she can send it to her daughter who has emigrated to Canada. She will be dead soon, she says, and her voice breaks as she reflects on how far away her family is.

The sense of nostalgia, transience and fragmentation that emerge from this combination of oral testimonies and visual images is reinforced by a range of different effects on the soundtrack that refer in one way or another to the passage 24 of time. As the camera moves along the benches, there is a ticking of a bicycle wheel. This sound, which was there on the original synch track all the time, but which was only discovered, so to speak, during the course of editing, acts as a sort of metronome, marking time. At various points, there is an intense cawing of the crows that gather in the trees at dawn and at dusk. Towards the end of the film, as dusk falls, an accordion player is shown in the middle distance and the soundtrack fills with schmaltzy old-time music ${ }^{7}$. These various sound effects, together with the sotto voce testimonies and fragmentary imagery, conspire to 
suggest the experience of memory itself, which, as the Romanian dramaturge Eugen Ionesco observes in a comment that serves as an epigraph to the film, lends a light to things that is 'the palest light of all'.

The ethereal qualities of In the Light of Memory are a far cry from the emotionally charged and all-too-physical memories that are presented in $A$ Cry from the Grave and Shoah. Instead of raging against loss and destruction, or building a monument to those who have suffered under the impact of major political events, In the Light of Memory testifies to changes in everyday experience in a resigned, philosophical manner. Rather than seeking traces of past events either in archival materials or in the residues left behind in bodies and environments, Alyssa Grossman's film actively breaks the link between the verbal relating of memories and any direct physical manifestation in the present-day real world. As such, it is neither more nor less effective than these earlier films, but instead merely different, and appropriately so, since it is intended to address a very different way in which memory comes to form part of human experience. It thus represents yet another mode whereby oral testimony may be combined with images and sounds within the genre of ethnographic film.

\section{NOTES}

1 See Henley (2009, p. 145-175) for an extended discussion of the methods used in this film.

2 See, for example, Turton (1992).

3 See Liebman (2007, p. 14) for a discussion of the use of visual archives in films about the Holocaust.

4 Lanzmann himself rejects any use of the term 'memory' in connection with the Holocaust because of its connotation of an event that is past. What I refer to here, using common anthropological parlance, as 'embodied memory', he refers to instead as an 'incarnation of the truth'. See Chevrie and Le Roux (2007, p. 41), and Liebman (2007, p. 9).

5 Chevrie and Le Roux 2007, p. 43.

6 Though this company was still in existence at the time that Shoah was filmed, it is now extinct, having been incorporated through a series of takeovers into the Daimler-Benz corporation.

7 Alyssa Grossman has explained (pers. comm. 2011) that the melody being played is Zaraza, which comes from a song that was popular during the interwar period in Romania. 'It evokes for Bucharest residents a particular social, cultural, and political atmosphere from a specific moment in Romania's past, when the city was considered the cultured "Paris of the East".

\section{REFERENCES}

BERNARD, H. Russell. Research methods in cultural anthropology: qualitative and quantitative approaches. 4. ed. Lanham: Altamira, 2005.

CHEVRIE, Marc; LE ROUX, Hervé. Site and speech: an interview with Claude Lanzmann about Shoah. In: LIEBMAN, Stuart (Ed.).Claude Lanzmann's Shoah: key essays. Oxford: Oxford University Press, 2007.p. 37-49.

HENLEY, Paul.The adventure of the real: Jean Rouch and the craft of ethnographic cinema. Chicago: University of Chicago Press, 2009.

HOBERMAN, J. Shoah: witness to annihilation. In: MACDONALD, Kevin; COUSINS, Mark (Eds.).Imagining reality: the Faber book of documentary. London; Boston: Faber and Faber, 1996.p. 322-325. 
LANZMANN, Claude. Shoah: an oral history of the Holocaust. New York: Pantheon, 1985.

. Hieristkeinwarum. In: LIEBMAN, Stuart (Ed.).Claude Lanzmann's Shoah: key essays. Oxford: Oxford University Press, 2007.p. 51-52.

LIEBMAN, Stuart. Introduction. In: . (Ed.).Claude Lanzmann's Shoah: key essays. Oxford: Oxford University Press, 2007.p. 3-24.

MACDOUGALL, David. Complicities of style. In: CRAWFORD, Peter; TURTON, David (Eds.).Film as ethnography. Manchester: Manchester University Press, 1992.p. 90-98.

Beyond observational cinema. In: HOCKINGS, Paul (Ed.).Principles of visual anthropology. 2. ed. New York; Berlin: Mouton de Gruyer, 1995.p. 115-132.

Films of memory. In: Transcultural cinema. Princeton, NJ: Princeton University Press, 1998.p. 231-244.

ROUCH, Jean. The camera and man. In: HOCKINGS, Paul (Ed.).Principles of visual anthropology. 2. ed. New York; Berlin: Mouton de Gruyer,1995.p. 79-98.

TURTON, David. How to make a speech in Mursi. In: CRAWFORD, Peter; SIMONSEN, Jan (Eds.).Ethnographic film aesthetics and narrative traditions. Aarhus: Intervention, 1992. p. 159-175.

WINSTON, Brian. Claiming the real: the documentary film revisited. London: British Film Institute, 1995. 